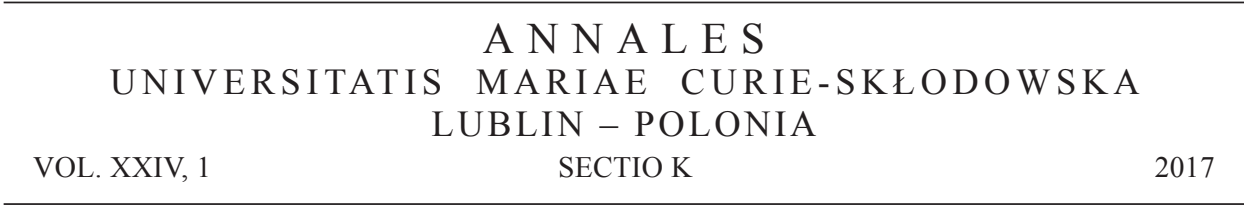

Institute of Political Science and International Affairs, John Paul II Catholic University of Lublin

\title{
European Union, Eastern Europe and Russia: Trilateral Relations in the Period of Ukraine's Crisis
}

\begin{abstract}
As a result of geopolitical changes which occurred on the verge of the 1980s and 1990s, the map of East-Central Europe underwent significant modifications. The enlargement of the EU encompassing Central European states (especially Poland) contributed to the change of the EU's attitude towards the post-Soviet space. Up to the time of the enlargement, due to the dominance of the "Russia first" policy, the EU did not recognize the need for tightening relations with post-Soviet states. After 2004, a gradual change in the EU's attitude towards its eastern neighborhood can be observed. The present paper aims to describe the EU's eastern policy in the period of crises: on the one hand, those plaguing the EU, and on the other, the so-called Ukrainian crisis. The crisis, a de facto, armed conflict between Russia and Ukraine, has resulted not only in a geopolitical change in Eastern Europe, but also exerted impact upon conditions the EU's eastern policy is realized in. In 2017, it is 8 years since the Eastern Partnership was implemented. The project, its achievements, objectives and opportunities need to be revisited. In other words, works on the Eastern Partnership 2.0 ought to be commenced. A change of both the approach and narration as far as the EaP project is concerned, is required. New areas and fields the EaP will offer opportunities for EaP-EU relations to be tightened ought to be discovered. The armed conflict in Ukraine, resulting in the instability of eastern neighborhood, constitutes a security challenge for the whole area of Eastern Europe.
\end{abstract}

Key words: European Union, Eastern Europe, Russia, Ukraine, Ukraine's crisis

\section{INTRODUCTION}

When viewing the map of East-Central Europe, it can be said that significant geopolitical changes in the region occurred on the verge of the 1980s and 1990s. At that time, international world order, including the one in Europe, was reconfigured. 
New states, liberated from Soviet chains and those released from satellite dependence on the USSR, emerged. Furthermore, the integration of Central European states (Poland, the Czech Republic, Hungary) with NATO (in 1999) and the EU (in 2004) is noteworthy. When compared with the reality of the beginning of the 1990s, the integration resulted in the emergence of a new geopolitical situation in East-Central Europe. The enlargement of the EU encompassing Central European states (especially Poland) contributed to the change of the EU's attitude towards the post-Soviet space. Up to the time of the enlargement, due to the dominance of the "Russia first" policy, the EU did not recognize the need for tightening relations with post-Soviet states. After 2004, a gradual change in the EU's attitude towards its eastern neighborhood can be observed. A further geopolitical change in Eastern Europe and the South Caucasus occurred in the aftermath of the five-days' war between Russia and Georgia (August 2008) [Stępniewski 2011: 209-212] and Russia's annexation of Crimea. The armed conflict in Donbas between Russia and Ukraine (raging since 2014) constitutes a fundamental challenge [determinants, course and significance of the conflict in Ukraine were broadly discussed in e.g. Harasimowicz 2016: 29-34; Delcour, Wolczuk 2015: 459-478; Haukkala 2015: 25-40; Judah 2015; Larrabee, Wilson, Gordon 2015; Shekhovtsov, Umland 2014; Wilson 2014; Barburska, Milczarek 2014; "Rocznik Instytutu Europy Środkowo-Wschodniej” 2014].

The present paper aims to describe the EU's eastern policy in the period of crises: on the one hand, those plaguing the EU, and on the other, the so-called Ukrainian crisis. The crisis, a de facto, armed conflict between Russia and Ukraine, has resulted not only in a geopolitical change in Eastern Europe, but also exerted impact upon conditions the EU's eastern policy is realized in. In other words, Russia's aggression on Ukraine placed the EU in a precarious position forcing the Union to change its policy towards Russia.

\section{CRISES IN THE EUROPEAN UNION}

Several crises and problems have emerged within the EU. Brexit, as one of these, constitutes a major challenge for the Union. For the first time in the history of the EU, a member state will leave the Community. As a consequence, the logic behind the functioning of the EU has changed. The change may bear negative consequences for countries aspiring for EU membership. In addition, other crises within the EU are present as well. These partly stem from problems with adjusting political systems of individual member states to the changing reality, which is a frequent outcome of external turmoil. According to Jan Zielonka, the EU is dealing not only with the crisis of democracy, but also the crisis of capitalism, European integration (the crisis of leadership and vision), migration, and a moral crisis (mentioned by Pope Francis in his speeches) [Żakowski 2016: 24]. An additional crisis, one pertaining to security systems, can be mentioned [Góralczyk 2014a: 233 ff]. Moreover, the situation in 
the international environment of the EU is troublesome as well. The fact does not remain without influence upon EU policy towards its neighbors. The following ought to be mentioned in this context: the war in Syria, operations in Libya, the overflow of migrants in the Mediterranean, the issue of the so-called Islamic State, Russia's neo-imperial policy (annexation of Crimea and support for separatisms in southern and eastern Ukraine), etc. [more on the issue in: Fiszer 2014: 33-52; Góralczyk 2014b; Stępniewski 2015a: 11-25].

\section{BREXIT AND ITS IMPACT UPON THE EU'S EASTERN POLICY}

In his speeches, David Cameron, former UK Prime Minister, emphasized the necessity of a referendum regarding the UK's membership in the EU. The referendum took place on 23 June 2016. The British voted to leave the EU (51.9\% supported leaving the EU, 48.1\% opposed) [Kaczorowska 2016: 39-61]. As a consequence, relations between the EU and UK must be revised. Several scenarios are considered. Two of these seem relatively probable: the first - preferential trade in bilateral relations, the second - the single market principle, will be maintained. The final shape of relations will largely depend upon the outcome of bilateral negotiations and decisions made by leading states of the EU, such as Germany, France, Italy, Spain, or even Poland. Interestingly, the ongoing negotiations, or rather chaos in negotiations between the UK and EU, result in the present relations between the EU and Ukraine becoming a model which may be potentially applied in relations between the EU and post-Brexit Britain. Timothy Garston Ash rightly observes that "the fact may be difficult to believe, but the UK is considering the EU-Ukraine relations among others as a model solution" [Ash 2017].

The UK's membership in the EU since 1973 influenced not only the shape of the Union's internal, but also international policy, including one towards Eastern Europe and Russia. Great Britain frequently placed emphasis upon enlargement and was skeptical with regard to Russia's policy towards Eastern Europe. Brexit denotes that the EU and its international policy will undergo changes. The withdrawal of the country exerting influence upon EU institutions may also change relations between the EU and countries of Eastern Europe. In addition, the UK frequently shared Poland's views regarding states of the Eastern Partnership and supported initiatives and projects addressing this part of the continent. It may be expected that Brexit will exert a negative impact not only upon Britain but also the whole EU. The prospective, negative influence upon the shape and direction of cooperation between the EU and Eastern Europe is of significance. 


\section{WHAT POLICY WILL THE EU APPLY IN RELATIONS WITH EASTERN PARTNERSHIP STATES?}

When analyzing the situation of Eastern Partnership states [more on the situation of countries encompassed by the European Neighborhood Policy and Eastern Partnership project in: Kostanyan 2017; Bouris, Schumacher 2016; Thompson 2015; Lannon 2015; Rieker 2014] in light of the armed conflict in Ukraine (the so-called Ukrainian crisis) [more on the crisis in: Youngs 2017a; Besier, Stokłosa 2017; Korosteleva 2016a; Natorski 2016; Sakwa 2016], the fact that the project faces a great challenge in the form of the so-called Ukrainian crisis, ought to be emphasized.

According to the representative of the European External Action Service (EEAS), the European Partnership (EaP) constitutes a mature project [Interview 1, 2016]. Despite the project losing its momentum and being implemented in specific conditions, the fact that resolutions of Vilnius and Riga summits are successfully implemented, cannot be disregarded. In addition, it ought to be emphasized that the chief problem of the EaP is the fact that the project is considered in geopolitical categories - as if EaP states faced the choice - gravitate either towards the EU or Russia (when listening to EU policy-makers, it seems that these countries have no other option). However, when developing the project, Poland and Sweden did not anticipate that countries in the project would face such a choice. The decision is extremely difficult to be made and entails several complications (in case of Ukraine these are of existential character). Obviously, the policy proves to be the most successful if associated with prospects of EU membership. The lack of such perspectives leads to the EU being unable to exert influence upon these countries [nterview 2, 2016]. However, the fact that EaP states are not ready for European integration (as far as virtually all membership criteria are concerned) cannot be disregarded. Moreover, according to the latest anticorruption rankings, in 2005 , Ukraine occupied $107^{\text {th }}$ position worldwide, whereas in 2015 , it ranked $142^{\text {nd }}$. In addition, not all countries under the EaP project declare the intention to integrate with the EU. On the one hand, Georgia, Moldova, and Ukraine express willingness to integrate and implement AA/DCFTA. On the other hand, Armenia, Azerbaijan, and Belarus do not manifest such intentions. However, recently, there have been discussions with Armenia regarding the country signing DCFTA (in a form which would not collide with Armenia's membership since 2014 in the Eurasian Union headed by Russia). If the talks regarding Armenia's signing the agreement succeed, the road will be paved to start similar negotiations with Azerbaijan and Belarus [Interview 1, 2016]. Moreover, as far as the prospects of integration with the $\mathrm{EU}$ are concerned, the remaining countries of the $\mathrm{EaP}$ are also divided.

Taking the internal situation of EaP states into consideration, the best option for cooperating with the EU would be to emphasize pragmatism, flexibility and search for cooperation opportunities. Obviously, still, EU policy ought to be based upon the "more for more" principle, which is no longer followed in the framework of the ENP. However, the EU ought to implement the "less for less" principle with regard 
to EaP states as well. The support of reforms in EaP states constitutes an example of such a pragmatic approach. Success of reforms determines the success of transformation in these countries. Should they fail, tightening relations between the EU and EaP states is unlikely to materialize. It ought to be clearly stated that the EU cannot do EaP states' homework for them. They must follow the path of changes and reforms themselves. Therefore, the EU ought to commit much greater financial resources to reforms in these countries. Naturally, in such a case, corruption poses a significant challenge.

The liberalization of visa travel constitutes a further issue. Moldova, Georgia, and lately Ukraine, were granted visa-free travel. Ukraine had already met all requirements posed by the EU, but the final decision was made only in the middle of 2017. The EU has also been developing a safety mechanism, i.e. the introduction of a suspension mechanism in case visa-free travel in the EU is abused by these countries. The fact that the mechanism was developed for the benefit of visa-free travel with Turkey worked against Ukraine. The combination of these issues delayed the introduction of the project for Ukraine and Georgia. Moreover, the fact that Ukraine does not control its whole territory ought to be remembered (Crimea was annexed by Russia, Donbas is war-torn). From the point of view of EU policy, it is vital that the public of these countries does not fall victim to the political situation. Citizens of EaP states ought to be able to travel to the EU freely. This is even more significant when the fact that the EU has placed emphasis on people-to-people contacts is considered. In addition, the EU ought to offer even more support to civil societies in EaP states, to young politicians and political leaders who seek changes, to free media, SMEs, etc. A premise can be made that it seems unlikely that political systems in these countries will remain unchanged in the near future. Therefore, the EU ought to support civil societies and bottom-up initiatives. It was public rebellion against Viktor Yanukovych, which was named the Euromaidan (also the Revolution of Dignity), in February 2014 in Ukraine, which resulted in a political change in the country. Therefore, it is evident that civil potential in Ukraine, and in other EaP states to a lower degree, is considerable, and EU decision-makers ought to keep that fact in mind.

\section{EASTERN EUROPEAN STATES IN RUSSIA'S NEO-IMPERIAL POLICY}

The fact that Eastern Partnership states do not operate in vacuum, but are dependent on internal and external determinants, is noteworthy. As far as external determinants are concerned, both the EU's and Russia's attitudes are of significance. Therefore, as far as EaP states are concerned, examining Russia's objectives (those real instead of those declared) towards these countries seems worthwhile. Both tactical and strategic objectives with regard to EaP states, and broadly post-Soviet space, are worth looking into. It can be said that since the outbreak of the Rus- 
so-Ukrainian war (a hybrid war, or a subliminal war), Russia has been striving to destabilize southern and eastern Ukraine in order to separate these regions, lead to the emergence of "occupied territories", or the establishment of a quasi-state (the case of Transnistria). The situation is playing out in the immediate neighborhood of V4 states, which exerts a direct impact upon the security of the Visegrad Group. The EU's and OSCE's preventive actions are critical to the stabilization of the situation in Ukraine [Stępniewski 2016a: 337-344].

According to Russian politicians, swift democratic changes in Ukraine pose a significant threat for Russia's interests and its political decision-makers. The fact that Ukraine's democratization will be possible with the assistance of western structures and close cooperation with these, is well established. Russia is aware of this fact. It is the reason behind its severe reactions to Ukraine's prospects for NATO and EU membership. It can even be risked that Russia's strategic objective towards Ukraine is to prevent the country's democratization and integration with the West [see: Stępniewski 2016b: 181-193; Korosteleva 2016b].

Sergey Karaganov, a well-known researcher frequently commenting in western media on Russia's international policy, observes that the Federation will never become a global power unless it becomes a regional one in the first place. Therefore, according to several researchers, Ukraine seems critical for Russia's superpower projects [Szabaciuk 2014: 75-86]. Undeniably, the Federation may become a regional superpower, and in the future, may play a key role in global politics. On the one hand, the war with Ukraine questions the achievement of these objectives. On the other hand, Russia's activity and military operations in Syria result in it becoming a significant player in both Near-East politics and global balance of powers.

Over the past two decades, Russia manifested considerable determination to reintegrate the post-Soviet space. From Russian perspective, ensuring hegemony in the space and diminishing western influence in the region contributes to the enforcement of its superpower status regionally and globally, and facilitates the achievement of several less significant objectives of socio-economic character. In addition, in order to defend its zone of influence, Russia did not hesitate to adopt a confrontational stance towards the West. However, the independence of Ukraine and remaining EaP states from Russia is clear and considerable. In other words, Russia applies numerous instruments to influence the internal situation of these countries [Stępniewski 2016a: 337-344; Korosteleva 2013: 11-36].

\section{CONCLUSIONS}

On the one hand, the EU's Eastern Partnership policy constitutes a long-term project, and should be viewed as such. On the other hand, according to Krzysztof Szczerski, it needs to be remembered that among all EU member states, there are those opposed, neutral, and supportive of the EU's eastern policy, including the 
Eastern Partnership initiative. The opposition encompasses countries interested in other geographical directions of EU influence or those which prioritize EU-Russia relations in the Union's eastern policy. Those neutral do not have their own geopolitical preferences - they are either too small and weak or see no difficulties in developing new directions in the EU's external policy. The supporters consider that the EaP, perceived as eastern policy, realizes their objectives to a greater or lesser extent. These states include three of the Visegrad Group: Poland, the Czech Republic, Hungary, but also, e.g. Sweden [Szczerski 2010: 55]. The fact that the success of the EU's eastern policy will be determined not only by member states, but also by addressees of the policy themselves, i.e. countries of Eastern Europe and the South Caucasus, is noteworthy.

In 2017, it is 8 years since the EaP was implemented. The project, its achievements, objectives and opportunities need to be revisited. In other words, works on the Eastern Partnership 2.0 ought to be commenced. The revision of the project seems vital in light of the EaP Summit planned for 2017 in Brussels. A change of both the approach and narration as far as the EaP project is concerned, is required. Symbols are crucial in politics, and the summit and the new opening of the project will offer such [wider: Stępniewski 2015b; Stępniewski 2016a: 337-344]. New areas and fields the EaP will offer opportunities for EaP-EU relations to be tightened ought to be highlighted. By doing so, opinions of experts and EaP politicians voicing concerns that the project failed will be undermined and such claims will become ungrounded. However, it cannot be forgotten that the EU has been pushing the condition of EaP states to the background. Therefore, it is critical that the Visegrad Group raise the issue of EaP states in European forum and support them so that the Russo-Ukrainian war in Donbas is not forgotten. The Ukrainian crisis poses a challenge not only for the security of Ukraine, but also for European and international security and order. According to Paul Ivan, the EU needs to highlight that it was Russia which annexed Crimea, it is the Federation that adds fuel to the war with Ukraine, and that it was Russia that broke international law [Interview with Paul Ivan, 2016]. Sanctions imposed by the EU against Russia constitute an apt reaction to the Federation's policy of accomplished facts. Therefore, the EU ought to enforce the realization of Minsk II agreement and its implementation by Russia.

To conclude, due to the fact that geopolitical situation in eastern neighborhood evolved, the EU's approach to EaP states ought to change. The armed conflict in Ukraine, resulting in the instability of eastern neighborhood, constitutes a security challenge for the whole area of Eastern Europe. In addition, Russia's increasingly assertive attitude towards eastern neighbors forces the EU to react. According to Richard Youngs, the armed conflict in Donbas resulted in the EU's change of approach towards its eastern neighbors. He defines the new approach as a hybrid or liberal-redux geopolitics [Youngs 2017b]. Moreover, Donald Trump, the new president of the USA, also seems insensitive to issues of Eastern Europe (especially Ukraine), which determines the emergence of new conditions for solving eastern matters. 


\section{BIBLIOGRAPHY}

Ash, T.-G. 2017. Chaos, zamęt i smutna królowa. W pierwsza rocznicę Brexitu, "Gazeta Wyborcza", 22 June 2017, http://wyborcza.p1/7,75968,21996813, chaos-zamet-i-smutna-krolowa-w-pierwsza-rocznicebrexitu.html (access: 22.06.2017).

Barburska, O., Milczarek, D. 2014. Polityka wschodnia Unii Europejskiej. Porażka czy sukces?, Oficyna Wydawnicza Aspra-JR, Warszawa.

Besier, G., Stokłosa, K. (eds.). 2017. Neighbourhood Perceptions of the Ukraine Crisis. From the Soviet Union into Eurasia?, Routledge, Oxon-New York.

Bouris, D., Schumacher, T. (eds.). 2016. The Revised European Neighbourhood Policy: Continuity and Change in EU Foreign Policy, Palgrave Macmillan, Basingstoke.

Delcour, L., Wolczuk, K. 2015. Spoiler or Facilitator of Democratization? Russia's Role in Georgia and Ukraine, "Democratization", vol. 22.

Fiszer J.-M. 2014. System transatlantycki w multipolarnym tadzie międzynarodowym: szanse i zagrożenia, [in:] Wspótpraca transatlantycka. Aspekty polityczne, ekonomiczne i społeczne, J. Fiszer, P. Olszewski, B. Piskorska, A. Podraza (eds.), Instytut Studiów Politycznych PAN, Fundacja Konrada Adenauera, Warszawa.

Góralczyk,B.J. 2014a. Unia Europejska jako aktor na scenie globalnej. Razem czy osobno?, Centrum Europejskie Uniwersytetu Warszawskiego, Warszawa.

Góralczyk, B.J. 2014b. The Crisis of 2008 and 2014 and the New Role of the European Union on the Global Scene, [in:] European Union on the Global Scene: United or Irrelevant?, B.J. Góralczyk (ed.), Centre of Europe, Warsaw.

Harasimowicz, A. 2016. Europejska polityka sasiedztwa - pechowa pierwsza dekada, "Studia Europejskie", no. 2, pp. 29-34.

Haukkala, H. 2015. From Cooperative to Contested Europe? The Conflict in Ukraine as a Culmination of a Long-Term Crisis in EU-Russia Relations, "Journal of Contemporary European Studies", vol. 23, no. 1.

Judah, T. 2015. In Wartime: Stories from Ukraine, Penguin, London.

Kaczorowska, M. 2016. Krajobraz polityczny po Brexicie, "Sprawy Międzynarodowe", rok LXIX, no. 3.

Korosteleva, E. 2013. Evaluating the Role of Partnership in the European Neighbourhood Policy: The Eastern Neighbourhood, "Eastern Journal of European Studies", vol. 4, no. 3.

Korosteleva, E. 2016a. The European Union, Russia and the Eastern Region: The Analytics of Government for Sustainable Cohabitation, "Cooperation and Conflict", vol. 51, no. 3.

Korosteleva, E. 2016b. EU-Russia Relations in the Context of the Eastern Neighbourhood, "Policy Brief", May.

Kostanyan, H. (ed.). 2017. Assessing European Neighbourhood Policy. Perspectives from the literature, CEPS, Rowman and Littlefield International, Brussels-London.

Lannon, E. 2015. More for More or Less for Less: From the Rhetoric to the Implementation of European Neighbourhood Instrument in the Context of the 2015 ENP review, "IEMed Overview", European Institute of the Mediterranean, Barcelona, http://www.iemed.org/observatori/arees-danalisi/arxius-adjunts/anuari/med.2015/IEMed\%20Yearbook\%202015_Panorama_ENPReview_ErwanLannon.pdf (access: 15.01.2017).

Larrabee, F.S., Wilson, P.A., Gordon IV, J. 2015. The Ukrainian Crisis and European Security: Implications for the United States and U.S. Army, RAND Corporation, Santa Monica.

Natorski, M. 2016. The EU and crisis in Ukraine: Policy continuity in times of disorder?, [in:] The Revised European Neighbourhood Policy: Continuity and Change in EU Foreign Policy, D. Bouris, T. Schumacher (eds.), Palgrave Macmillan, Basingstoke.

Rieker, P. 2014. The European Neighbourhood Policy: An Instrument for Security Community Building, NUPI Working Paper, no. 832, Norwegian Institute of International Affairs, Oslo.

"Rocznik Instytutu Europy Środkowo-Wschodniej” (2014), Majdan 2014: Ukraina na rozdrożu. 
Sakwa, R. 2016. Frontline Ukraine: Crisis in the Borderlands, I.B. Tauris, London.

Shekhovtsov, A., Umland, A. 2014. Ukraine's Radical Right, "Journal of Democracy”, vol. 25, no. 3.

Stępniewski, T. 2011. Geopolityka regionu Morza Czarnego w pozimnowojennym świecie, Instytut Europy Środkowo-Wschodniej, Lublin-Warszawa.

Stępniewski, T. 2015a. Unia Europejska, Ukraina i Rosja: kryzysy i bezpieczeństwo, "Studia Europejskie", no. 4(76).

Stępniewski, T. 2015b. ENP Or ENPs? The curious web of the European Neighbourhood Policy: the Southern and Eastern Dimensions revisited, "Rocznik Instytutu Europy Środkowo-Wschodniej”, zeszyt 4.

Stępniewski, T. 2016a. The European Union and Eastern Partnership: Crises and Strategic Assessment, "Rocznik Instytutu Europy Środkowo-Wschodniej”, zeszyt 5.

Stępniewski, T. 2016b. The Eastern Policy of the European Union. The Role of Poland, "POLITEJA. Pismo Wydziału Studiów Międzynarodowych i Politycznych Uniwersytetu Jagiellońskiego”, no 41.

Szabaciuk, A. 2014. Eurazjatycki projekt integracyjny Władimira Putina: szanse i zagrożenia, "Rocznik Instytutu Europy Środkowo-Wschodniej”, zeszyt 5.

Szczerski, K. 2010. Polityka wschodnia Unii Europejskiej a strategia Grupy Wyszehradzkiej, [in:] Partnerstwo Wschodnie w kontekście Europejskiej Polityki Sasiedztwa i agendy Grupy Wyszehradzkiej, I. Albrycht (ed.), Instytut Kościuszki, Kraków-Bruksela.

Thompson, J. 2015. The Global Players in the EU's Broader Neighbourhood, [in:] The Neighbours of the European Union's Neighbours: Diplomatic and Geopolitical Dimensions Beyond the European Neighbourhood Policy, S. Gstöhl, E. Lannon (eds.), $1^{\text {st }}$ edition, Ashgate Publishing Ltd., Farnham.

Wilson, A. 2014. Ukraine Crisis: What It Means for the West, Yale University Press, New Haven, CT.

Youngs, R. 2017a. Is "Hybrid Geopolitics" the Next EU Foreign Policy Doctrine?, "Carnegie Europe", 19 June 2017, http://carnegieeurope.eu (access: 19.06.2017).

Youngs, R. 2017b. Europe's Eastern Crisis. The Geopolitics of Asymmetry, University Press, Cambridge. Żakowski, J. 2016. Ogniska choroby. Politolog Jan Zielonka o globalnym kryzysie demokracji, "Polityka", $1.01-12.01$, no. $1 / 2(3041)$.

\section{INTERVIEWS}

Interview 1, European External Action Service (EEAS), Headquarters Brussels; Russia Division, 15 September 2016.

Interview 2, Permanent Representation of the Republic of Poland to the European Union, Brussels, 13 September 2016.

Interview with Paul Ivan from the European Policy Centre, Brussels, 12 September 2016.

\section{BIOGRAPHY}

Tomasz Stępniewski, Doctor Habilitatus (The Polish Academy of Sciences, Warsaw, Poland). Associate professor and chair-holder of Eastern Studies Chair at the Institute of Political Science and International Affairs, Faculty of Social Sciences (The John Paul II Catholic University of Lublin). His research interests include the European Union's eastern policy, international relations of the Commonwealth of the Independent States' area, Russia's policy towards Eastern Europe. E-mail: tomasz.stepniewski5@gmail.com 